Paideusis

\title{
"John Dewey and the Art of Teaching: Toward Reflective and Imaginative Practice" (Douglas J. Simpson, Michael P. Jackson, and Judy C. Aycock)
}

\section{James Scott Johnston}

Volume 16, Number 1, 2007

URI: https://id.erudit.org/iderudit/1072610ar

DOI: https://doi.org/10.7202/1072610ar

See table of contents

Publisher(s)

Canadian Philosophy of Education Society

ISSN

0838-4517 (print)

1916-0348 (digital)

Explore this journal

Cite this review

Johnston, J. (2007). Review of ["John Dewey and the Art of Teaching: Toward Reflective and Imaginative Practice" (Douglas J. Simpson, Michael P. Jackson, and Judy C. Aycock)]. Paideusis, 16(1), 69-71. https://doi.org/10.7202/1072610ar 
Review of

\title{
John Dewey and the Art of Teaching: Toward Reflective and Imaginative Practice
}

by Douglas J. Simpson, Michael P. Jackson, and Judy C. Aycock, Thousand Oaks, CA: Sage

Publications, 2005

\author{
JAMES SCOTT JOHNSTON \\ Queen's University, Canada
}

Educational theory seems to have fallen on hard times. Alternatively, perhaps it is more correct to say that some aspects of educational theory have diminished, in favour of others. Certainly, history and philosophy of education are less and less represented in faculties of education and teachers' colleges. Educational psychology, cognitive studies, and indeed, cultural studies, seem to be flourishing. All of these can be considered theory. Moreover, all of them promote or claim to promote (however differently) reflective practice_-or at least, all of these have this as one of their mandates.

Yet it is common to hear that teachers no longer have access to the tools and resources necessary to conduct reflective practices. Despite the prevalence of theory in faculties of education and teachers' colleges, there is a vast literature suggesting that teachers lack (or at least, have a lack of access to) reflective practice. Educational theory, on its own definition, is that branch of education organized to provide students with the tools for reflective practice and we may wonder whether educational theory is 'doing its job' if reflective practitioners are not developing.

Douglas B. Simpson, Michael B. Jackson and Judy C. Aycock are also concerned about reflective practice and the development of reflective practitioners. This is their avowed reason for writing John Dewey and the Art of Teaching. Unhappy with the current state of affairs in teacher education, and certain of the need for thoughtful assistance to teachers and teacher candidates, the authors have written an engaging and easily readable primer on reflective practice with John Dewey's educational thought front and centre.

The authors cull statements of Dewey's from a variety of texts and articles, including Dewey's famous educational works, Democracy and Education, The Sources of a Science of Education, and Experience and Education. The authors develop these statements into metaphors for teaching. These metaphors include the teacher as artist, lover, wise mother, navigator, gardener, educational pioneer, servant, social engineer, composer, wise physician, builder, leader, and finally (to bring it all back) classroom teacher. Each of these metaphors is found in one or another of Dewey's writings; the authors work through these statements of Dewey's, and form from them a picture of the reflective teacher.

The metaphor of teacher as artist, however, informs the rest. There has been a spate of Dewey scholarship suggesting that the best metaphor to understand teaching practice is that of the artist, and the best metaphor to understand Deweyan thought is through the lenses of art and aesthetic experience. Phillip Jackson and Jim Garrison are notable exemplars of this line of thinking. On this model, teachers are artists that construct their practice in and through, better and more satisfying,

(C) Copyright 2007. The author, James Scott Johnston, assigns to Paideusis the right of first publication and educational and nonprofit institutions a non-exclusive license to use this document for personal use and in courses of instruction provided that the article is used in full and this copyright statement is reproduced. Any other usage is probibited without the express permission of the author. 
experiences. An experience is a basic element of what it is to be human-indeed, alive. We have experiences and through these, we adjust, adapt, and learn to control our environments such that we can develop further and better experiences. We 'undergo,' and we 'do,' as Dewey famously says, and between doing and undergoing, we grow.

Education is the means to this growth, to having and undergoing better and better experiences. The artistry comes in both at the level of having an experience (aesthetic experiences are said to be the 'highest' or to use Dewey's preferred terminology, 'consummatory') and the tools, resources, indeed, reflection that we use to order our experiences. A reflective practitioner is thoughtfully engaged in altering her practice to achieve the deepest and fullest experiences for herself and her students. Reflection in this case is subservient to the experience, but vital to the task.

The authors develop the metaphor of artistry through the other metaphors. Some of these metaphors may be self-evident (the teacher as Leader; the teacher as Navigator). Others may not (the teacher as Wise Mother; the teacher as Social Engineer). It is worth spending a bit of time on these two admittedly odd metaphors to see what the authors have in mind.

The metaphor of teacher as Wise Mother suggests that the teacher emulates as best as possible the home learning environment of the child. As the authors say,

If only we could, we might occasionally wish to clone these caregivers [parents] and homes if it wouldn't destroy individuality and freedom and artistry. So would Dewey, and he would like to begin by transporting from these desirable homes characteristics and qualities that are relevant to teaching and learning in schools. Of course, Dewey recognizes that there are degrees of providing healthy home environments. No home is completely devoid of positive qualities; neither is any home a totally positive environment. (Simpson, Jackson \& Aycock, 2005, p. 44).

Dewey "values it [the image of the home] as a model of learning, engagement, and development and encourages us to make our schools similar" (Simpson, Jackson \& Aycock, p. 46). Indeed, Dewey does say that the rich home life of the child is to be the point of departure for the activities of the classroom. One of the challenges of (especially primary) education is to connect the activities of the school with those at home and in so doing, give rise to the child's natural curiosity and interest.

Another odd metaphor is that of the Social Engineer. What do the authors have in mind? Here, the focus is on the social constructor. The authors look to Dewey's statements on science, and specifically, Dewey's (1991) statements in The Sources of A Science of Education. In this text, the emphasis is on the systematic methods, intelligently used, to bring forth better teaching practices. The key here is intelligent use; this is central to the idea of a reflective practitioner. As the authors say,

\footnotetext{
When future and current teachers are viewed as "channels of reception and transmission" (LW 5: 24), we can't expect even the best scientific research and philosophical reflection to be valued by them or influence learning and schooling positively. Educators, whether university professors or district personnel, who attempt to pour ideas, data, theories, philosophies, values, plans, and strategies into teachers are not only doing an injustice to research and reflective thought but are also ensuring that what we teach will more likely to be "badly deflected and distorted" (LW 5: 24). (Simpson, Jackson \& Aycock, 2005, p. 48)
}

The metaphor of the teacher as social engineer is the metaphor of the constructor. This is the idea that teaching and learning are not a passive affair, but an active construction occurring between teacher and student. However, the metaphor of the teacher as social engineer has, as the authors point out in a footnote, worrisome implications. The image of the bureaucrat, planning the construction of society without democratic or public input, is a challenge put to Dewey by social critics such as Christopher Lasch, and sceptics of educational history such as Clarence Karier and Paul Hogan. Certainly, the authors do not wish to invoke the sense of the social engineer. A better term could perhaps have been found to get the idea across. 
Throughout the text are several pedagogical tools designed to stimulate the reader to think. Questions are fairly distributed throughout each of the chapters, designed to have the reader focus on her practice. A summative exercise is included at the end of each chapter, to bring the thoughts of the reader together. Dewey's quotes are developed in detail in sections of each chapter, and helpful figures are provided to represent complex claims and ideas. The book is relatively short (218 pages) and the chapters seldom pass beyond 15 pages. This obviates a tedious read.

There are only two caveats that come with this book. One has to do with content: the other style or form. In terms of content, the authors do an able job of presenting Dewey's thoughts and understandings of what it is to be a teacher. I notice, however, that a central element of Dewey's thinking-perhaps as or even more central than the metaphor of teacher as artist-is the metaphor of teacher as inquirer. This is not to say that the authors ignore this. In fact, they devote the better part of a chapter to problem solving (in the Teacher as Builder). Nevertheless, inquiry is often downplayed throughout the text and this misrepresents Dewey; Dewey spent far more time and ink talking about the 'science' of education than the art. And while this should not compel us to rank the metaphor of teacher as artist below that of teacher as inquirer, we should pause before assigning the former preeminent status.

The second caveat concerns the audience for this book: While this book draws heavily on Dewey and uses statements of Dewey's liberally, it is not (nor is it intended to be) Dewey scholarship. The book's purpose is to spur the development of reflective teacher practice, not to debate what Dewey really said. The audience for this book is teachers and teacher candidates looking for guidance in forming their practices, rather than students of Dewey scholarship. If this audience is kept in mind, this book will be very valuable, indeed. For it takes what I believe are among the best ideas of educational theory and places them in the context of reflective practice. For this alone, the book is well worth using. I recommend this book to faculties of education attempting to develop reflective practice amongst teacher candidates and practicing teachers looking for inspired understandings of what it means to teach.

\section{References}

Dewey, John. (1991). The sources of a science of education — individualism old and new. In The collected works of John Dewey: The later works $1925-1952$ (Ed. by J. A. Boydston; pp. 1-40). Carbondale, IL: Southern Illinois University Press.

Simpson, Douglas J., Jackson, M. B., \& Aycock, J. C. (2005). John Dewey and the art of teaching: Toward reflective and imaginative practice. Thousand Oaks, CA: Sage Publications. 